\title{
Immunoregulatory effects of $\alpha$-interferon. Effects on in-vitro antibody synthesis by lymphocytes from patients with rheumatoid arthritis
}

\author{
B K PELTON AND A M DENMAN
}

From the Connective Tissue Disease Research Group, Clinical Research Centre, Harrow, Middlesex HAl $3 U J$

SUMmARY The immunosuppressive effects of $\alpha$-interferon (IFN) on the in-vitro synthesis of specific anti-influenza virus antibody by lymphocytes from 20 healthy donors were compared with those from 12 patients with rheumatoid arthritis. No differences were observed between the two groups. IFN suppressed the induction of in-vitro antibody synthesis by lymphocytes from rheumatoid donors but did not affect antibody synthesis once this had been initiated. Furthermore, the IFN-mediated suppression of antibody synthesised by rheumatoid lymphocytes could also be reversed by B cell helper supernatant. These findings make it unlikely that $\alpha$-IFN affects established B cell responses characteristic of the rheumatic diseases.

Key words: antibody formation, connective tissue disease, immunosuppression.

Previous reports have described the presence of interferon (IFN) in the serum of patients suffering from systemic lupus erythematosus (SLE), ${ }^{1-3}$ rheumatoid arthritis, scleroderma, and Sjögren's syndrome. ${ }^{4}$ This interferon has the characteristics of $\alpha$-interferon, since it is neutralised by anti- $\alpha$-IFN antibody. ${ }^{1-3}$ Two forms of IFN have been found in the serum of patients with SLE, one being stable at pH $2^{3}$ and the other acid labile. ${ }^{12}$ Hence serum IFN in patients with connective tissue disorders might influence the immunoproliferative events characteristic of these disorders.

In a previous paper, ${ }^{5}$ we showed that $\alpha$-IFN suppresses the specific antibody response of normal lymphocytes but not established antibody synthesis. Therefore we have examined the effect of $\alpha$-IFN on the in-vitro antibody response of peripheral blood mononuclear cells from patients with rheumatoid arthritis. Our objectives were firstly, to determine whether the susceptibility of lymphocytes from patients with this disorder to $\alpha$-IFN differed from those of normal donors and secondly, to see if the abnormal B cell proliferation characteristic of this disorder was likely to be affected by $\alpha$-IFN.

The results show that in-vitro antibody synthesis by lymphocytes from normal donors and from rheumatoid arthritis patients is equally susceptible to the immunosuppressive effects of $\alpha$-IFN. In contrast, antibody synthesis induced by exposure to antigen and a polyclonal $B$ cell stimulant is unaffected by $\alpha$-IFN.

\section{Materials and methods}

\section{SUBJECTS}

Twelve patients with classic seropositive rh:cumatoid arthritis fulfilling the American Rheumatism Association (ARA) criteria $^{6}$ for this disease were selected. None of these patients had received corticosteroids, cytotoxic or second line drugs. They were immunised with $0.5 \mathrm{ml}$ MFV-Ject influenza vaccine (Servier Laboratories Ltd, Greenford, Middlesex) 10 days prior to study.

Three patients with SLE were studied, all of whom fulfilled the ARA criteria for diagnosis of this disease. ${ }^{7}$ These patients were not receiving corticosteroids or cytotoxic drugs at the time of study and all patients had 'active disease' judged by clinical and laboratory findings. ${ }^{8}$ These patients were not immunised.

The controls were as described in a previous paper; ${ }^{9}$ their age and sex distribution was not 
significantly different from that of the patients studied. These studies were approved by the Northwick Park Hospital Ethical Committee.

\section{ANTIBODY SYNTHESIS IN VITRO}

Human peripheral blood lymphocytes prepared on Ficoll-Hypaque gradients were cultured at a concentration of $2 \times 10^{9}$ cells/l with X31 influenza virus (5 $\mathrm{mg} / \mathrm{l}$ ) in RPMI 1640 containing $10 \%$ horse serum. After six days incubation at $37^{\circ} \mathrm{C}$ in an atmosphere of $5 \% \mathrm{CO}_{2}$ in air, cells were washed twice and resuspended in $0.5 \mathrm{ml}$ of RPMI 1640 containing $5 \%$ fetal calf serum. After 24 hours incubation at $37^{\circ} \mathrm{C}$ culture supernatants were removed and tested for anti-influenza antibody by ELISA assay. Full details of these procedures are published elsewhere. ${ }^{5}$

\section{IN T ER F ERON}

Partially purified human lymphoblastoid interferon (Wellcome Laboratories, Beckenham, Kent) was used throughout this study.

\section{B CELL HELPER SUPERNATANT}

Peripheral blood mononuclear cells from a single donor were obtained by Ficoll (Pharmacia) sedimentation, and the preparation depleted of adherent cells by incubation on Nunc tissue culture dishes for $90 \mathrm{~min}$. T and non-T cells were obtained by incubating the non-adherent cells with $1 \%$ sheep red blood cells treated with neuraminidase. ${ }^{10}$ The rosetted cells were separated by further Ficoll gradients, ${ }^{11}$ and the $\mathrm{B}$ cells purified by rerosetting with neuraminidase-treated sheep cells. The separated $T$ cells were irradiated with 2000 rads by exposure to a cobalt source. Irradiated $\mathrm{T}$ cells were cultured with autologous $B$ cells at a ratio of $2: 1$ and a cell concentration of $2 \times 10^{9}$ cells $/ 1$, in $25 \mathrm{ml}$ of RPMI 1640 (Flow Laboratories Ltd) containing 5\% fetal calf serum and $4 \mathrm{mg} / \mathrm{l}$ pokeweed mitogen (PWM). The cells were cultured for 48 hours at $37^{\circ} \mathrm{C}$ in an atmosphere of $5 \% \mathrm{CO}_{2}$ in air, then washed four times in RPMI 1640, and recultured for a further 72 hours before harvesting the supernatant factors. Supernatants obtained in this manner enable purified $B$ cells to proliferate and secrete immunoglobulin, and have the same growth promoting characteristics as those described previously. ${ }^{12}$ They were also free from residual PWM as confirmed by radioimmunoassay. ${ }^{12}$

MEASUREMENT OF SPONTANEOUS IgG PRODUCTION

Peripheral blood lymphocytes from patients with SLE were cultured at a concentration of $2 \times 10^{9}$ cells/l in RPMI 1640 containing $10 \%$ fetal calf serum without antigenic or polyclonal mitogen stimulation. $\overrightarrow{\vec{F}}$ After seven days' incubation at $37^{\circ} \mathrm{C}$ in an atmosphere of $5 \% \mathrm{CO}_{2}$ in air the culture supernatants? were tested for IgG by solid phase radio- $\frac{\bar{N}}{\bar{N}}$ immunoassay. ${ }^{9}$ To exclude the possibility of serum ${ }_{\bar{\sigma}}$ carry-over or release of cytophilic IgG during $\cong$ culture samples of the culture fluid were assayed foros IgG after 4 hours and 24 hours, but none was $\vec{\circ}$ detected. Cultures to which $0.05 \%$ sodium azide was added did not synthesise IgG.

\section{Results}

ANTIBODY SYNTHESIS IN VITRO BY RA LYMPHOCYTES

Eight of the 12 RA patients responded to in-vitro $\vec{\omega}$ challenge with influenza virus antigen by producing 9 specific antibody. The mean antibody response was $4.4 \mathrm{units} / \mathrm{ml}$. This response is not significantly different from that of 11 out of 20 normals who produced a mean antibody level of 3.4 units $/ \mathrm{ml}^{-}$ $(p<0.086)$ during the same period (Fig. 1).

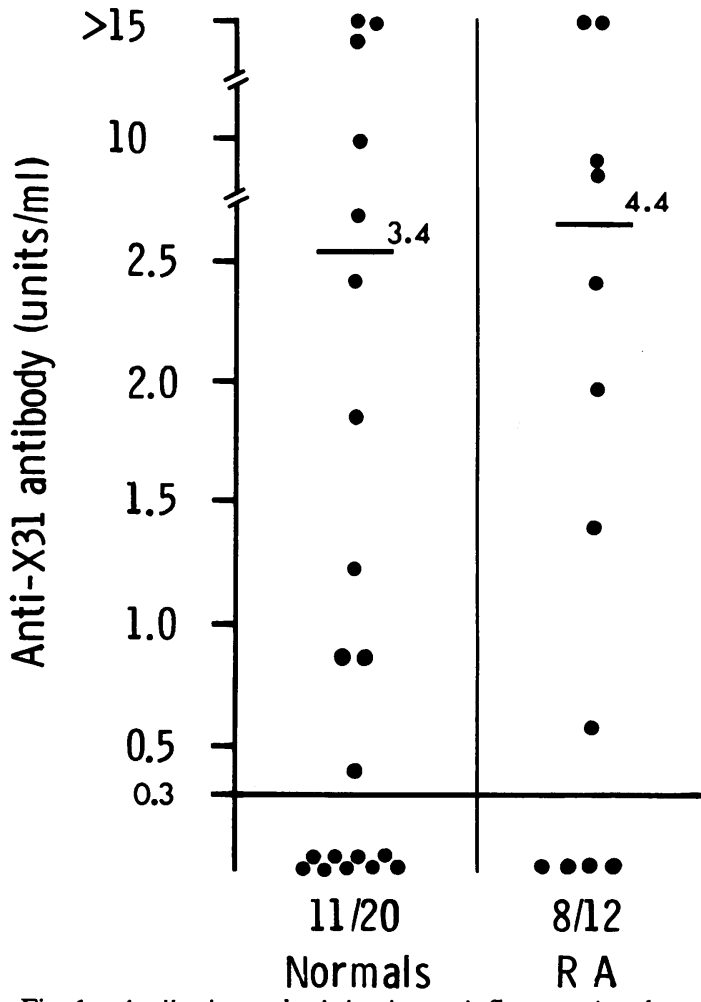

Fig. 1 Antibody synthesis in vitro to influenza virus by human peripheral blood from immunised donors. Donors were immunised 10 days prior to study. Each value is a representation of duplicate assays on duplicate cultures. 
EFFECTS OF $\alpha$-INTERFERON ON IN-VITRO ANTIBODY SYNTHESIS BY RA LYMPHOCYTES One thousand units of $\alpha$-IFN added simultaneously with antigen were immunosuppressive $(p<0.02)$. Similar results were obtained when $\alpha$-IFN was added 24 hours after antigen, but not when the same amount of interferon was added at 72 hours. Ten units of $\alpha$-IFN were only slightly suppressive $(\mathrm{p}<0 \cdot 88)$, even if added simultaneously with antigen (Fig. 2).

ADDITION OF B CELL FACTOR

$B$ cell factor added to antigen(Ag)-stimulated cultures of rheumatoid arthritis (RA) mononuclear cells increased the production of specific antibody (Fig. 3). In one case we observed production of

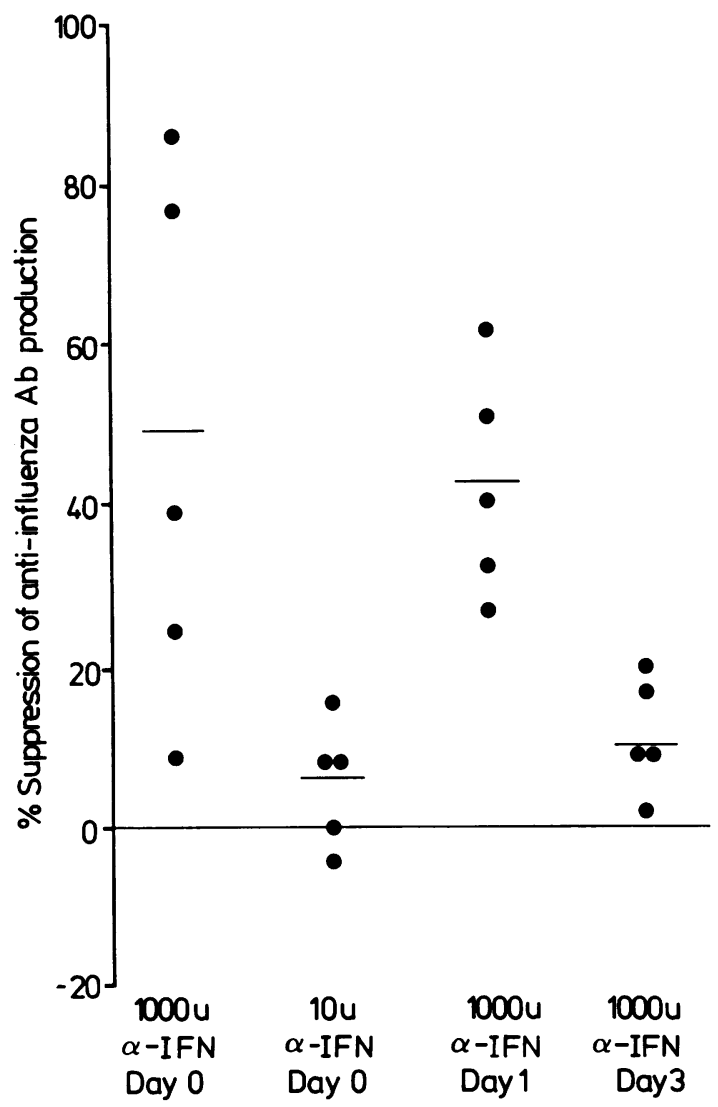

Fig. 2 Antibody ( $A b$ ) synthesis of RA lymphocytes suppressed by $\alpha$-interferon added simultaneously with antigen but not when added at 72 hours. Results are means for duplicate assays from five individual donors. Percentage suppression refers to the amount of antibody produced in a culture compared with the amount produced in cultures containing antigen alone from the same individual.

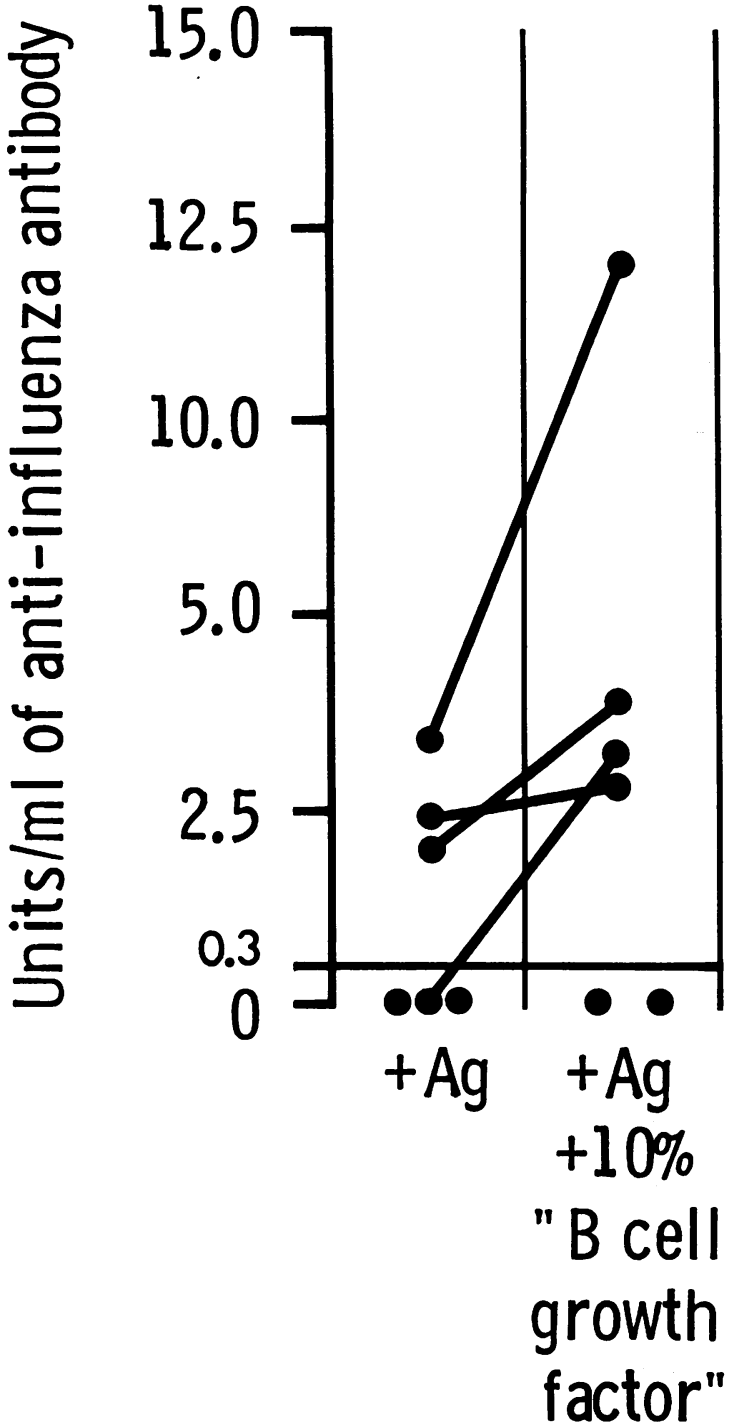

Fig. 3 Enhanced antibody production in cultures of $R A$ lymphocytes in the presence of $B$ cell factor. Results are means for duplicate assays from six individual donors. The lines indicate paired observations on the same donor.

antibody in a culture from a donor whose lymphocytes failed to respond to antigen alone (Fig. 3).

EFFECT OF IFN ON ANTIBODY SYNTHESIS

IN VITRO IN THE PRESENCE OF B CELL

FACTOR

Neither 1000 (Fig. 4) nor 100 units (data not shown) of $\alpha$-IFN suppressed antibody production by cul- 


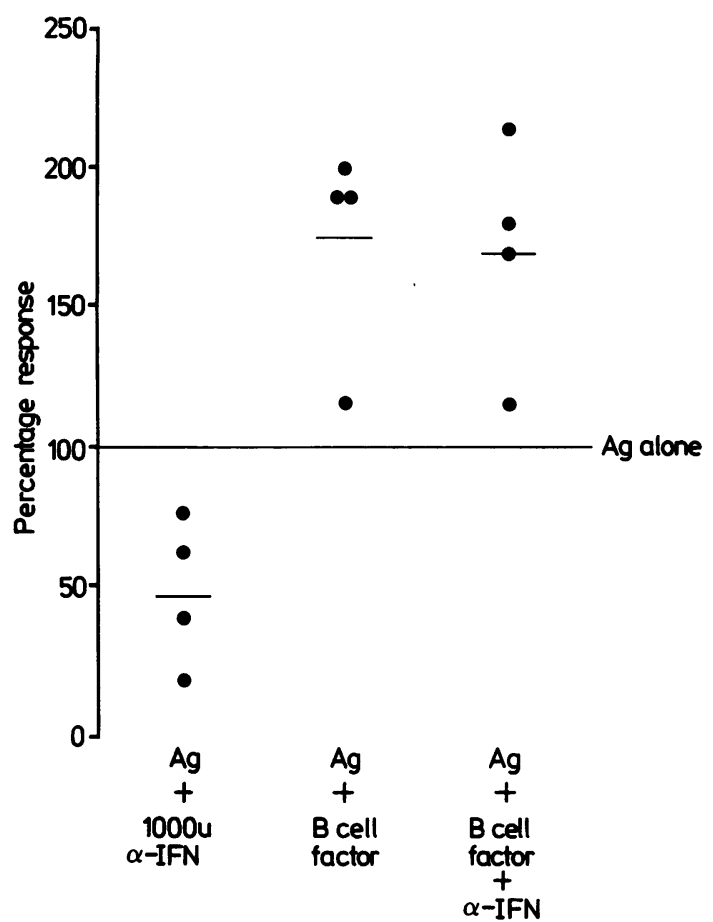

Fig. 4 Failure of $\alpha-I F N$ to suppress antibody synthesised by $R A$ lymphocytes in the presence of $B$ cell factor. $B$ cell factor was added to the appropriate cultures at $10 \% \mathrm{v} / \mathrm{v}$. Values are means from duplicate assays from four donors. Percentage response refers to cultures containing additional material as indicated, compared with antigen-stimulated cultures from the same individual.

tured RA lymphocytes to which B cell factor as well as antigen had been added (Fig. 4).

EFFECT OF IFN ON SPONTANEOUS PRODUCTION OF IgG

One thousand units of $\alpha$-IFN added to cultures of SLE lymphocytes, which were synthesising IgG

Table 1 Failure of $\alpha$-IFN to suppress spontaneous IgG production by SLE lymphocytes

\begin{tabular}{|c|c|c|}
\hline \multirow[t]{2}{*}{ Patient } & \multicolumn{2}{|c|}{ IgG production (mg/l) } \\
\hline & $\begin{array}{l}\text { In presence } \\
\text { of } \alpha-I F N \\
\text { Mean SD }\end{array}$ & $\begin{array}{l}\text { In absence } \\
\text { of } \alpha-I F N \\
\text { Mean SD }\end{array}$ \\
\hline 1 & $1.13 \quad 0.07$ & $1.26 \quad 0.05$ \\
\hline 2 & $0.86 \quad 0.08$ & $\begin{array}{ll}0.82 & 0.11\end{array}$ \\
\hline 3 & $3.4 \quad 0.46$ & $2.98 \quad 0.39$ \\
\hline
\end{tabular}

Results are means with (SD) from duplicate assays on three donors. Appropriate cultures received 1000 units of $\alpha$-IFN on day 0 of culture. spontaneously without added antigen, did not pre- $\frac{\square}{\infty}$ vent the continued secretion of Ig (Table 1).

\section{Discussion}

The objective of this present study was to determine whether $\alpha$-IFN could account for the suspected immunoregulatory abnormalities in patients with rheumatoid arthritis. Previously several authors have examined the serum of patients with autoimmune diseases for the presence of IFN. ${ }^{1-4}$ Originally IFN was found in the serum of patients with SLE, RA, scleroderma, and Sjögren's syndrome and because of its properties was thought to be $\gamma$-IFN. ${ }^{4}$ This finding was later modified to suggest the presence of multiple types of IFN and finally, $\alpha$-IFN, labile at $\mathrm{pH} 2 \cdot 0 .{ }^{1}$ This latter finding has been confirmed. $^{2}$ These findings, coupled with the observation that $\alpha$-IFN increases PWM-driven Ig synthesis in vitro, ${ }^{13}$ have led some authors to postulate that the continuous presence of IFN may contribute to immunological aberrations in autoimmune diseases. ${ }^{4}$ This idea receives some support from the observation that in NZB mice the administration of mouse IFN accelerates the onset and increases the severity of the autoimmune disease. ${ }^{14} 15$

Our results do not support the idea that serum IFN influences the immunoproliferative events of RA. The antibody response of RA lymphocytes to a conventional antigen was as readily suppressible by interferon as that induced in normal lymphocytes, and indeed previous experiments have confirmed that purified $\alpha$-IFN exerts a similar effect. ${ }^{5}$ In addition, RA lymphocytes were simultaneously exposed to specific antigen and a polyclonal activating factor in vitro ${ }^{12}$ in order to simulate the postulated events of in-vivo polyclonal stimulation, which may underlie B cell proliferation in RA. ${ }^{16}$ Specific antibody stimulated in this manner was unaffected by $\alpha$-IFN, though the doses used were consistent with those observed in vivo, that is, between 200 and 500 units $/ \mathrm{ml}$ of serum. ${ }^{17}$

Though the highest serum levels of $\alpha$-IFN have been detected in patients with SLE, ${ }^{4}$ we were $N$ unable to study specific in-vitro antibody production in this disease, since we have previously shown that a defect in blood B lymphocytes from patients with active SLE results in a failure of these cells to respond to influenza virus antigen in vitro. ${ }^{18} \mathrm{How}$ ever, we were able to show that spontaneous Ig production by lymphocytes from this disease was unaffected by the addition of IFN, again indicating $\stackrel{\curvearrowright}{\overparen{D}}$ that prestimulated B lymphocytes are resistant.

In this paper we have examined the effect of one 
kind of interferon on antibody synthesis. Thus we have failed to show that $\alpha$-interferon influences established patterns of $\mathrm{B}$ cell proliferation in RA. However, it is still possible that $\alpha$-IFN and other forms of interferon disrupt the regulation of other kinds of immune response.

\section{References}

1 Hooks J J, Jordan G W, Cupps T, Moutsopoulos H M, Fauci A S, Notkins A L. Multiple interferons in the circulation of patients with SLE and vasulitis. Arthritis Rheum 1982; 25: 396-400.

2 Preeble $O$ T, Black R J, Friedman R M. SLE: presence in human serum of an unusual acid-labile leukocyte interferon. Science 1982; 216: 429-31.

3 Ytterberg S R, Schnitzer T J. Serum interferon levels in patients with SLE. Arthritis Rheum 1982; 25: 401-6.

4 Hooks J J, Moutsoupoulos H M, Geis S A, Stahl N I, Decker J L, Notkins A L. Immune interferon in the circulation of patients with autoimmune disease. $N$ Engl J Med 1979; 301: 5-8.

5 Pelton B K, Denman A M. Immunoregulatory effects of $\alpha$-interferon 1. $\alpha$-interferon inhibits in vitro antibody synthesis by normal human lymphocytes. In press.

6 Ropes M W, Bennett G A, Cobb S, Jacox R, Jessar R A. 1958 revision of diagnostic criteria for rheumatoid arthritis. Bull Rheum Dis 1958; 9: 175-6.

7 Tan E M, Cohen A S, Freis J F, et al. The 1982 revised criteria for the classification of systemic lupus erythematosus. Arthritis Rheum 1982; 25: 1271-3.
8 Hollingworth $\mathrm{P}$, De Vere Tyndall A, Ansell G M, et al. Intensive immunosuppression versus prednisolone in the treatment of connective tissue diseases. Ann Intern Med in press.

9 Pelton B K, Imrie R C, Denman A M. Susceptibility of human lymphocyte populations to infection by herpes simplex virus. Immunology 1977; 32: 803-10.

10 Bentwich Z, Douglas S D, Skutelsky E, Kunkel H G. Sheep red cell binding to human lymphocytes treated with neuraminidase: enhancement of $T$ cell binding and identification of a sub-population of B cells. J Exp Med 1973; 137: 1532-7.

11 Hersey P, Edwards E, Edwards J. Characterization of mononuclear effector cells in human blood. Clin Exp Immunol 1976; 23: $104-13$.

12 North M E, Brenner M K. Induction of immunoglobulin and antigen-dependent antibody synthesis in human lymphocytes using supernatants from mitogen-stimulated cultures. Immunology 1983; 48: 157-63.

13 Harfast B, Huddlestone J R, Casali P, Merigan T C, Oldstone M B A. Interferon acts directly on human B lymphocytes to modulate immunoglobulin synthesis. J Immunol 1981; 127: 2146-50.

14 Heremans H, Billiau A, Colombatti A, Hilgers J, De Somer P. Interferon treatment of NZB mice; accelerates progression of autoimmune disease. Infect Immun 1978; 21: 925-30.

15 Adam C, Thoua Y, Renco P, Verroust P, Tovey M, MorelMaroger $L$. The effect of exogenous interferon: acceleration of autoimmune and renal disease in (NZB/W) F1 mice. Clin Exp Immunol 1980; 40: 373-82.

16 Denman A M. Immunosuppression and the rheumatic diseases. Ann Rheum Dis 1982; 41 (suppl 1), 3-8.

17 Stewart W E. The interferon system. New York: Springer-Verlag, 1979: 17.

18 Pelton B K, Denman A M. Defective B cell function in SLE. Clin Exp Immunol 1982; 48: 513-8. 